\section{The Institution of Metallurgists}

AT the nineteenth annual general meeting of the Institution of Metallurgists, Dr. L. Northcott, principal superintendent, Materials Division, Royal Armament Research and Development Establishment, Fort Halstead, War Office, was elected president of the Institution for the year 1963-64, in succession to Dr. E. G. West. The following elections were made: Vice-Presidents, Dr. I. Jenkins (director of Metallurgical Research, Manganese Bronze, Ltd.) and Prof. G. V. Raynor (Feeney professor of physical metallurgy, University of Birmingham); Honorary Treasurer, Mr. L. W. Derry (head of Metallurgy Department, Battersea College of Technology); Ordinary Members of Council elected by the Fellows, Dr. W. A. Baker (technical manager, Alcan Industries, Ltd.) and $\mathrm{Mr}$. T. F. Pearson (research manager, Consett Iron Co.); Ordinary Member of Council elected by the Associates, Mr. A. Prince (chief metallurgist, Hirst Research Centre, the General Electric Co., Wembley, Middlesex).

\section{Beit Memorial Fellowships}

THE following elections to Beit Memorial fellowships have been announced: Junior Fellowships, W. L. Ford, to continue his researches into the role of lymphocytes in immune responses, at the Sir William Dunn School of Pathology, Oxford; M. D. Casey, to investigate chromosome abnormalities in a particular sub-group of psychiatric patients, at the Department of Genetics, University of Sheffield; Dr. D. Franks, to continue his researches into the antigenic structure of cell lines in culture, at the Department of Pathology, Cambridge; Dr. T. K. Sundaram, to undertake a detailed study of interallelic genetic complementation in the mould, Neurospora crassa, at the John Innes Institute, Bayfordbury, Herts.; W. B. J. Broom, to study the mode of action of carbon dioxide in accelerating hypothermia, at the Department of Physiology and the Institute of Clinical Research, Middlesex Hospital Medical School, London; M. A. Siddiqui, to carry out cell population studies in the thymus after treatment with certain alkane sulphonic esters that induce lymphopænia, at the Department of Experimental Chemotherapy, Christie Hospital, Manchester; Dr. E. K. Matthews, to investigate the electropharmacology of chromaffin cells, at the Department of Pharmacology, Cambridge. Fourth Year Fellowships, Dr. E. R. Huehns, to continue his researches into the final stages of the biosynthesis of hæmoglobin and the æetiology of thalassæmia, at the Department of Biochemistry, University College, London, and the Medical Unit, University College Hospital Medical School, London; Dr. A. J. Rowe, to continue his researches into the molecular architecture of the contractile filaments of a mammalian myofibril, at the Medical Research Council Laboratory of Molecular Biology, Cambridge.

\section{The Royal Aeronautical Society}

Honorary fellowship of the Royal Aeronautical Society has been conferred on Mr. W. Littlewood, vice-president, Equipment and Research, American Airlines, Inc., and Sir Alfred Pugsley, professor of civil engineering and provice-chancellor, University of Bristol. Honorary companionship of the Society has been awarded to: Mr. C. H. Gibbs-Smith, keeper of extension services, Victoria and Albert Museum; Mr. C. L. Pashley, manager and chief flying instructor, Southern Aero Club; Sir Richard Orme Wilberforce (the Hon. Mr. Justice Wilberforce is chairman of the Society's Air Law Group).

Awards of the Society's Medals have been made as follows: The Gold Medal, to Mr. H. Constant, scientific adviser to the Air Ministry, for his outstanding contributions to gas turbine development; The Silver Medal, to Mr. L. H. Bedford, director of engineering, British Aircraft Corporation (Guided Weapons), Ltd., for his outstanding work on guidance systems; The Bronze Medal, to Mr. H. H. Pearcey, of the National Physical Laboratory, for his contributions to the advancement of aerodynamics; The British Gold Medal for Aeronautics, to Mr. A. C. Lovesey, director and chief engineer, AeroEngine Division, Rolls-Royce, Ltd., for his outstanding practical achievement in aero engine design and development; The British Silver Medal for Aeronautics, to Mr. B. P. Laight, chief engineer, Advanced Projects Group, Hawker Siddeley Aviation, Ltd., formerly chief designer, Blackburn Aircraft, Ltd., for his practical achievement in the design of low-level strike aircraft; The Wakefield Gold Medal, to Lord Brabazon of Tara, for his outstanding contributions to air-safety over many years; The R. P. Alston Medal, to Mr. C. F. Bethwaite, deputy chief engineer (Aero), A. V. Roe and Co., Ltd, for his practical achievements in flight-test observation work; The Alan Marsh Medal, to Wing Commander K. H. Wallis, who by his personal initiative, resourcefulness and piloting ability has made an outstanding contribution to the study of rotary wing flight.

\section{Leverhulme Research Awards, 1963}

THE following fellowships and research grants, among others, tenable for periods of up to two years, have been announced by the Leverhulme Trustees: Fellowships, Dr. A. D. Bradshaw (University College of North Wales, Bangor), for an examination of the factors maintaining polymorphisms in populations of plants. Research grants, Dr. F. R. Allchin and Dr. B. Allchin (University of Cambridge), for the preparation of a text-book on the prehistory of India, Pakistan and Ceylon; Mr. H. K. Bowes (engineer), for a scientific analysis of decorated samian ware; Mr. G. Lewis (University of Oxford), to carry out work on the evolutionary significance of polymorphism exemplified by the banding pattern in the shell of certain helicid molluses; Dr. D. M. Needham (private research worker), for the preparation and writing of a book on the biochemistry of muscle contraction; Dr. P. Nield (development chemist), for investigations in organic chemistry.

\section{The Night Sky in July}

FULL moon occurs on July $6 \mathrm{~d} 21 \mathrm{~h} 56 \mathrm{~m}$ U.T. and new moon on July $20 \mathrm{~d} 20 \mathrm{~h} 43 \mathrm{~m}$. The following conjunctions with the Moon take place: July $9 \mathrm{~d} 19 \mathrm{~h}$, Saturn $2^{\circ} \mathrm{N}$.; July 13d 19h, Jupiter $4^{\circ} \mathrm{N}$.; July $25 \mathrm{~d} 10 \mathrm{~h}$, Mars $5^{\circ} \mathrm{N}$. There is a partial eclipse of the Moon on July 6-7, mainly visible at Greenwich. Moon enters penumbra July 6d $19 \mathrm{~h} 17.0 \mathrm{~m}$, Moon enters umbra $20 \mathrm{~h} 32.0 \mathrm{~m}$, mid-eclipse is at $22 \mathrm{~h} 02.4 \mathrm{~m}$, Moon leaves umbra $23 \mathrm{~h} 32.8 \mathrm{~m}$, and Moon leaves penumbra July $7 \mathrm{~d}$ oh $47 \cdot 7 \mathrm{~m}$. Maximum magnitude is 0.711 ; moonrise at Greenwich July $6 \mathrm{~d} 20 \mathrm{~h}$ $04 \mathrm{~m}$. There will be a total eclipse of the Sun on July 20 . invisible at Greenwich; a partial eclipse will be visible shortly before sunset in Scotland and Northern Ireland. Mercury and Venus are too close to the Sun for easy observation. Mars is visible in the evenings in the west, setting about two hours after the Sun; conditions for observation are now unfavourable. Jupiter rises at $0 \mathrm{~h}$ $00 \mathrm{~m}, 23 \mathrm{~h} 05 \mathrm{~m}$ and $22 \mathrm{~h} 05 \mathrm{~m}$ on July 1,15 and 31 , respectively. It is in Pisces, its stellar magnitude is $-2 \cdot 1$ and its distance from the Earth on July 15 is 445 million miles. Saturn rises at $22 \mathrm{~h} 20 \mathrm{~m}, 21 \mathrm{~h} 30 \mathrm{~m}$ and $20 \mathrm{~h} 20 \mathrm{~m}$ at the beginning, middle and end of the month, respectively. It is in Capricornus, its stellar magnitude is $+0 \cdot 6$ and its distance from the Earth on July 15 is 835 million miles. There are no occultations of stars brighter than magnitude 6 visible at Greenwich. The $\delta$ Aquarid meteors are active July 15-August 10 , with maximum July 30 , the radiant being near R.A. $22 \mathrm{~h} 36 \mathrm{~m}$, Dec. $-17^{\circ}$; conditions are fairly favourable. The Earth is at aphelion on July 4, the distance from the Sun being 94.6 million miles. 